Collection: COST Action FP0903 (2010) - Rome (Italy)

"Research, monitoring and modelling in the study of climate change and air pollution impacts on forest ecosystems"

Guest Editors: E Paoletti, J-P Tuovinen, N Clarke, G Matteucci, R Matyssek, G Wieser, R

Fischer, P Cudlin, N Potocic

\title{
Availability and evaluation of European forest soil monitoring data in the study on the effects of air pollution on forests
}

\author{
Cools N, De Vos B
}

In the study of air pollution effects on forest ecosystems, solid soil data such as cation exchange capacity, base saturation and other exchangeable cation fractions, soil texture, soil moisture, soil weathering rates, $\mathrm{C} / \mathrm{N}$ ratio and other variables form an important information base for many air pollution impact models. This paper shows some of the possibilities and the limitations of the soil data that European countries collected on the systematic Level I and on the intensive and permanent Level II monitoring plots within the ICP Forests programme. The soil data date from a first inventory in the 1990 s and from a second inventory more than 10 years later. Both surveys were conducted following a common manual on sampling and analysis of soil. An example of the changes in $\mathrm{pH}\left(\mathrm{CaCl}_{2}\right)$ and base saturation in the forest floor and mineral soil on more than 2000 plots till a depth of $80 \mathrm{~cm}$ between the two surveys is presented. In this period the $\mathrm{pH}\left(\mathrm{CaCl}_{2}\right)$ significantly increased in the very acid forest soils [with $\mathrm{pH}\left(\mathrm{CaCl}_{2}\right)$ below 4.0] but further decreased in forest soils with $\mathrm{pH}\left(\mathrm{CaCl}_{2}\right)$ above 4.0. Following the trend in $\mathrm{pH}$, the base saturation increased in soils with a very low buffering capacity (soils with a base saturation below $20 \%$ in the first inventory) and decreased in forest soils with reference base saturation values above $20 \%$. There is both a decrease of soil $\mathrm{pH}$ and base saturation in the forest floor of the Arenosols and Podzols. In the Podzols this decreasing trend could not be established in the mineral soil, though this decreasing trend persisted in a number of mineral soil layers of the Arenosols. The only consistent increasing trend of $\mathrm{pH}$ and base saturation when stratifying according to the WRB reference soil groups was seen in the forest floor of the Luvisols and Cambisols.

Keywords: Forest soils, Soil acidification, Soil monitoring, ICP Forests

\section{Introduction}

One of the factors influencing the condition of European forests is the persistent input of atmospheric pollutants (Fischer et al. 2007, Lorenz \& Granke 2009). In addition to the direct damage to trees, the indirect effects of atmospheric pollutants through the soil are one of the main reasons for the deterioration of the condition of forest ecosystems (De Schrijver et al. 1998, van Breemen et al. 1982, 1984). An examination of the soil of the European forests provides basic information on the chemical condition of the soil and the nutrient supply to the trees, as well as the influence of pollutant inputs on the soil condition. There are clear correlations between forest soil chemistry and the deposition of acidity and heavy metals (De Schrijver et al. 1998, Nilsson \& Tyler 1995 , Eriksson et al. 1992, Fernandez et al. 2003,
Hernandez 2003). Therefore a soil condition assessment provides information on soil related stress factors for forest condition, evidenced by nutrient imbalances or impaired growth.

Since 1985, an annual assessment of the crown condition of forest trees has been carried out within the framework of the International Co-operative Programme on Assessment and Monitoring of Air Pollution Effects on Forests (ICP Forests) of the UN/ECE Convention on Long-range Transboundary Air Pollution and the European Union scheme on the protection of forests against atmospheric pollution. In addition, the condition of the European forest soils is monitored at an approximately time interval of 10 years. A first forest soil condition inventory (using a grid of $16 \times 16 \mathrm{~km}$ ) was executed by 30 countries between 1985 and $\square$ Forest Soil Coordinating Centre (FSCC), Research Institute for Nature and Forests (INBO), Gaverstraat 4, B-9500 Geraardsbergen (Belgium)

@ Nathalie Cools (Nathalie.Cools@inbo.be) Received: Nov 30, 2010 - Accepted: May 15, 2011

Citation: Cools N, De Vos B, 2011. Availability and evaluation of European forest soil monitoring data in the study on the effects of air pollution on forests. iForest 4: 205-211 [online 2011-11-03] URL: http://www.sisef.it/iforest/show.php? id $=588$

1996. The results showed a correlation between the soil chemistry and the atmospheric deposition of nitrogen and acidity. Extremely acid topsoil conditions were found on forest plots located almost exclusively in regions receiving very high atmospheric deposition loads (Vanmechelen et al. 1997). A second soil inventory was carried out between 2006 and 2008 within the "BioSoil" demonstration project of the Forest Focus Regulation of the European Commission (DG Environment). One of the aims of the project was to check whether a second survey after approximately 10 years could detect any changes in selected soil parameters. To process the data of the first soil inventory ICP Forest set up the Forest Soil Co-ordinating Centre (FSCC). Further activities of the FSCC are to maintain and improve the soil data from the forest soil condition inventory by updating the Manual on Sampling and Analysis of Soil (Cools \& De Vos 2010a) and by controlling the quality of the laboratory analysis by organising interlaboratory comparisons every other year (Cools et al. 2003, 2004, 2006, 2007, Cools \& De Vos 2010b).

The BioSoil survey completes the soil information on the European level and assesses relevant soil parameters, soil layers and plots not considered in the first survey. On the plots that are reassessed within BioSoil, it provides information on changes in soil chemistry. Within the Framework of the EU LIFE+ FutMon project, FSCC is evaluating the data of this second pan-European forest soil inventory.

This paper aims at providing insight in the possibilities and the limitations of the European forest soil database managed by ICP Forests. In a second part a comparison over time is made of two soil properties important in the assessment of the vulnerability to air pollution: soil reaction $\left(\mathrm{pH}\right.$ in $\left.\mathrm{CaCl}_{2}\right)$ and base saturation. 
Tab. 1 - The four main components of the forest soils database of ICP Forests.

\begin{tabular}{lcccc}
\hline \multicolumn{1}{c}{$\begin{array}{c}\text { Monitoring } \\
\text { Network }\end{array}$} & Level I & Level II & Level I & Level II \\
\hline $\begin{array}{l}\text { Time span of field } \\
\text { sampling }\end{array}$ & $1985-1996$ & $1990-2000$ & $2004-2008$ & $2006-2009$ \\
$\mathrm{~N}^{\circ}$ plots & 5289 & & & \\
$\mathrm{~N}^{\circ}$ countries & 30 & 738 & 4928 & 127 \\
Sampled layers & Forest floor & Forest floor & OL, OFH layer, H and & OL, OFH layer, H and \\
& $0-10 \mathrm{~cm}$ & $0-10 \mathrm{~cm}$ & peat layers & $0-(5)-10 \mathrm{~cm}$ \\
& $10-20 \mathrm{~cm}$ & $10-20 \mathrm{~cm}$ & $0-(5)-10 \mathrm{~cm}$ & $10-20 \mathrm{~cm}$ \\
& & $20-40 \mathrm{~cm}$ & $10-20 \mathrm{~cm}$ & $20-40 \mathrm{~cm}$ \\
& & $40-80 \mathrm{~cm}$ & $20-40 \mathrm{~cm}$ & $40-80 \mathrm{~cm}$ \\
& & or recalculated & $40-80 \mathrm{~cm}$ & \\
Sampled horizons & from horizons & none & main genetic horizons & main genetic horizons \\
Methods and measured & ICP-Forests Manual & ICP-Forests Manual & ICP-Forests Manual IIIa (2006); \\
soil variables/parameters & (UN-ECE 1994); & (UN-ECE 1994) & Guidelines for soil description (FAO 2006); \\
& Commission Regulation EEC & Soil geographical database of Eurasia and the Medi- \\
& no. 926/93 (CEC 1993) & terranean: instruction guide 4.0 (Lambert et al. 2003) \\
\hline
\end{tabular}

\section{Material and methods}

Monitoring networks

The ICP Forests large-scale Level I forest condition monitoring network provides an annual overview on forest condition based on a $16 \times 16 \mathrm{~km}$ gridnet covering around 6000 plots in Europe. Surveys include an annual crown condition assessment by the inventory of defoliation, discolouration and damage visible to the trees, foliar chemistry analysis and soil chemistry analysis every 10 years. Complementary to Level I, the intensive monitoring programme on approximately 800 Level II plots provides insight into causes affecting the condition of forest ecosystems and into effects of different stress factors. The major forest types of Europe are represented. Monitoring at these plots includes the assessment of tree growth, crown condition, chemical composition of foliage and soil, and species composition of the ground vegetation on most plots, whereas atmospheric deposition, meteorological variables, soil solution chemistry, ambient air quality, litterfall and phenology are monitored at a subset of Level II plots. In addition, the monitoring of ephiphytic lichens, stand structure and deadwood is being tested on 90 plots.

\section{Soil variables}

The forest soil database of ICP Forests consists of 4 main parts (Tab. 1). An overview of the actual content and completeness of the soil database of the Level I soil inventory of the first inventory between 1985 and 1996 is given in Tab. 2. The data availability in the 10-20 cm (not shown here) layer is intermediate between the $0-10 \mathrm{~cm}$ (surface layer) and the $20-40 \mathrm{~cm}$. A similar soil survey was mainly conducted in 1995-1996 on 742 Level II plots. Here the soil variables $\mathrm{pH}\left(\mathrm{CaCl}_{2}\right)$, total organic carbon and total or-
Tab. 2 - Number of plots and percentage of total number of plots for which the given variable/parameter for the soil layer under consideration is available in the ICP Forests Level I database of the 1985-1996 survey.

\begin{tabular}{|c|c|c|c|c|c|c|}
\hline \multirow{2}{*}{ Parameters } & \multicolumn{2}{|c|}{ Forest floor } & \multicolumn{2}{|c|}{ 0-10 cm layer } & \multicolumn{2}{|c|}{$20-40 \mathrm{~cm}$ layer } \\
\hline & No. plots & $\%$ & No. plots & $\%$ & No. plots & $\%$ \\
\hline \multicolumn{7}{|c|}{ General parameters } \\
\hline Altitude class (50 m intervals) & 5289 & 100 & - & - & - & - \\
\hline Soil unit (FAO, 1989) & 5013 & 95 & - & - & - & - \\
\hline Parent material & 2132 & 40 & - & - & - & - \\
\hline \multicolumn{7}{|c|}{ Soil parameters at layer level } \\
\hline Texture (measured or estimated) & - & - & 3430 & 65 & 510 & 10 \\
\hline Bulk density (measured or estimated) & - & - & 2259 & 43 & 371 & 7 \\
\hline Coarse fragments (measured or estimated) & - & - & 2448 & 46 & 551 & 10 \\
\hline Organic layer mass & 4400 & 83 & - & - & - & - \\
\hline $\mathrm{pH}\left(\mathrm{CaCl}_{2}\right)$ & 4262 & 81 & 4686 & 89 & 996 & 19 \\
\hline Total N & 4670 & 88 & 4633 & 88 & 996 & 19 \\
\hline $\mathrm{OC}$ & 4471 & 85 & 4636 & 88 & 995 & 19 \\
\hline Carbonate content & 325 & 6 & 1099 & 21 & 553 & 10 \\
\hline Exchangeable elements & 1115 & 21 & 2984 & 56 & 987 & 19 \\
\hline Macronutrients (P, K, Ca, Mg) & 3173 & 60 & 869 & 16 & 338 & 6 \\
\hline $\begin{array}{l}\text { Micronutrients and heavy metals } \\
(\mathrm{Na}, \mathrm{Fe}, \mathrm{Al}, \mathrm{Mn}, \mathrm{Cd}, \mathrm{Cr}, \mathrm{Cu}, \mathrm{Ni}, \mathrm{Pb}, \mathrm{Zn})\end{array}$ & 1503 & 28 & 573 & 11 & 3 & 4 \\
\hline
\end{tabular}

Tab. 3 - Number of plots and percentage of total number of plots for which the given variable/parameters for the organic layer is available in the BioSoil Level I database of the 20062008 survey.

\begin{tabular}{lcccc}
\hline \multirow{2}{*}{\multicolumn{1}{c}{ Parameters }} & \multicolumn{2}{c}{ OFH-layer } & \multicolumn{2}{c}{ H-layers (peat) } \\
\cline { 2 - 5 } & N plots & \% & N plots & \% \\
\hline $\mathrm{pH}\left(\mathrm{CaCl}_{2}\right)$ & 3546 & 72 & 241 & 95 \\
$\mathrm{pH}\left(\mathrm{H}_{2} \mathrm{O}\right)$ & 2848 & 58 & 231 & 91 \\
$\mathrm{Total} \mathrm{N}$ & 3544 & 72 & 241 & 95 \\
$\mathrm{OC}$ & 3544 & 72 & 241 & 95 \\
Organic layer mass & 3476 & 71 & 144 & 56 \\
Carbonate content & - & 0 & 15 & 6 \\
Exchangeable elements & 2784 & 56 & 201 & 79 \\
Macro - and micronutrients, heavy & 3934 & 80 & 241 & 95 \\
metals & & & & \\
Total elements (Al, Ca, Fe, K, Mg, & 133 & 3 & - & - \\
Mn, Na) & & & & \\
Acid oxalate extractable Fe and Al & 1321 & 27 & 110 & 43 \\
\hline
\end{tabular}


Tab. 4 - Number of plots and percentage of total number of plots for which the given variable/parameters for the mineral surface and subsur face layer is available in the BioSoil Level I database of the 2006-2008 survey.

\begin{tabular}{|c|c|c|c|c|c|c|}
\hline \multirow{2}{*}{ Parameters } & \multicolumn{2}{|c|}{$0-10 \mathrm{~cm}$} & \multicolumn{2}{|c|}{$20-40 \mathrm{~cm}$} & \multicolumn{2}{|c|}{$40-80 \mathrm{~cm}$} \\
\hline & No. plots & $\%$ & No. plots & $\%$ & No. plots & $\%$ \\
\hline Texture class (and \% clay, silt and sand) & 3722 & 80 & 3228 & 69 & 2958 & 63 \\
\hline Measured or estimated bulk density of the fine earth & 4180 & 89 & 3228 & 69 & 2926 & 63 \\
\hline Coarse fragments (vol \% or mass \%) & 3549 & 76 & 2614 & 56 & 2268 & 49 \\
\hline $\mathrm{pH}\left(\mathrm{CaCl}_{2}\right)$ & 4350 & 93 & 3320 & 71 & 3036 & 65 \\
\hline $\mathrm{pH}\left(\mathrm{H}_{2} \mathrm{O}\right)$ & 3586 & 77 & 3195 & 68 & 2910 & 62 \\
\hline Total Organic Carbon & 4345 & 93 & 3320 & 71 & 3035 & 65 \\
\hline Total N & 4345 & 93 & 2774 & 59 & 2534 & 54 \\
\hline Carbonates & 1130 & 24 & 902 & 19 & 873 & 19 \\
\hline Exchangeable acidity, free $\mathrm{H}, \mathrm{Fe}, \mathrm{Al}, \mathrm{Mn}, \mathrm{Ca}, \mathrm{K}, \mathrm{Mg}, \mathrm{Na}$ & 3956 & 85 & 3245 & 69 & 2927 & 63 \\
\hline Macronutrients $(\mathrm{P}, \mathrm{Ca}, \mathrm{K}, \mathrm{Mg}, \mathrm{Mn})$ & 3977 & 85 & 2593 & 55 & 2373 & 51 \\
\hline Micronutrients and heavy metals $(\mathrm{Cu}, \mathrm{Pb}, \mathrm{Cd}, \mathrm{Zn}, \mathrm{Al}, \mathrm{Fe}, \mathrm{Cr}, \mathrm{Ni}, \mathrm{S}, \mathrm{Na})$ & 4046 & 87 & 1409 & 30 & 1366 & 29 \\
\hline Acid oxalate extractable $\mathrm{Al}$ and $\mathrm{Fe}$ & 2473 & 53 & 2392 & 51 & 2179 & 47 \\
\hline Total Al, Ca, Fe, K, Mg, Mn, Na & 543 & 12 & 496 & 11 & 393 & 8 \\
\hline
\end{tabular}

ganic nitrogen are covered for nearly $100 \%$ in the organic layer and the mineral surface layer. Concentrations of exchangeable elements exist for $96 \%$ of the plots for the mineral surface layer. Information on the aqua regia extractable macronutrients is available for $90 \%$ of the organic layers. On the other hand, data on physical soil properties (soil texture, amount of coarse fragments, bulk density) is very limited on the Level II plots of the first inventory.

In the second soil inventory leading to the BioSoil database, additional variables, samples and sampling depths were included. See Tab. 3 and Tab. 4. The data availability on the $10-20 \mathrm{~cm}$ depth layer (not shown here) is again intermediate between the surface ( 0 -10 $\mathrm{cm})$ and the subsurface layers $(20-40 \mathrm{~cm}$ and $40-80 \mathrm{~cm})$.

\section{Quality assurance and quality control}

In the period between the first and the second forest soil inventory the FSCC and the Expert Panel on Soil and Soil Solution of ICP Forests made major efforts to improve the quality of the soil data through the regular update of the Manual on Sampling and Analysis of Soil (Cools \& De Vos 2010a), by the organisation of interlaboratory comparisons (Cools et al. 2003, Cools et al. 2004, Cools et al. 2006, Cools et al. 2007, Cools \& De Vos 2010b) and by the distribution of a forest soil reference material. Important improvements in the BioSoil database compared to the database based on the first inventory are:

The application of harmonised methods in the field:

- All countries use the same fixed depth intervals [0-(5)-10-20-40-80 cm] for sampling of the composite samples. Sampling according to horizons is restricted to the sampling of the profile pit mainly for soil classification purposes.

- The organic layer is not sampled as a whole but according to the subhorizons
$\mathrm{OL}, \mathrm{OF}, \mathrm{OH}, \mathrm{Hf}, \mathrm{Hfs}, \mathrm{Hs}$ ) and peat layers are designated with a separate code.

- A minimum number of subsamples are to be included in the composite sample.

- Minimum requirements have been set to the sampling design concerning the spatial distribution of the sampling points across the monitoring plot.

The laboratory methods have been refined, for example:

- Particle size distribution is to be conducted by the pipette method (ISO 11277 1998) and the texture class is derived using the USDA texture triangle (FAO 1990);

Tab. 5 - The plotwise paired mean difference of $\mathrm{pH}\left(\mathrm{CaCl}_{2}\right)$ in the forest floor and the four fixed depth mineral layers $(0-10 \mathrm{~cm}, 10-20 \mathrm{~cm}, 20-40 \mathrm{~cm}$ and $40-80 \mathrm{~cm})$ according to $5 \mathrm{pH}$ classes for common plots in the Level I surveys of 1985-1996 and 2004-2008. The last 2 columns show the $95 \%$ confidence interval (95\% C.I.) after bootstrapping the mean difference and an indication if this mean difference is significant different from zero (no change). $(* *)$ : significant at $95 \%$ confidence limits; (ns): not significant.

\begin{tabular}{lcccccc}
\hline \multicolumn{1}{c}{ Layer } & $\begin{array}{c}\text { pH } \\
\text { Class }\end{array}$ & $\begin{array}{c}\text { pH }\left(\mathbf{C a C l}_{2}\right) \\
\text { range }\end{array}$ & $\begin{array}{c}\text { No. } \\
\text { observations }\end{array}$ & $\begin{array}{c}\text { Mean } \\
\text { difference }\end{array}$ & $\begin{array}{c}\text { 95 \% } \\
\text { C.I. }\end{array}$ & Prob. \\
\hline Forest floor & 1 & $\leq 3.2$ & 292 & 0.18 & {$[0.15 ; 0.22]$} & $* *$ \\
(OF \&OH layer) & 2 & $3.2-4$ & 498 & -0.01 & {$[-0.04 ; 0.03]$} & ns \\
& 3 & $4-5$ & 324 & 0.01 & {$[-0.04 ; 0.07]$} & ns \\
& 4 & $5-6$ & 186 & -0.04 & {$[-0.13 ; 0.05]$} & ns \\
& 5 & $>6$ & 144 & -0.20 & {$[-0.3 ;-0.11]$} & $* *$ \\
& - & whole & 1444 & 0.01 & {$[-0.01 ; 0.04]$} & ns \\
\hline Mineral topsoil & 1 & $\leq 3.2$ & 119 & 0.27 & {$[0.21 ; 0.33]$} & $* *$ \\
$(0-10 \mathrm{~cm})$ & 2 & $3.2-4$ & 829 & 0.06 & {$[0.04 ; 0.08]$} & $* *$ \\
& 3 & $4-5$ & 583 & -0.04 & {$[-0.08 ; 0.001]$} & $* *$ \\
& 4 & $5-6$ & 199 & -0.19 & {$[-0.27 ;-0.1]$} & $* *$ \\
& 5 & $>6$ & 452 & -0.19 & {$[-0.24 ;-0.15]$} & $* *$ \\
& - & whole & 2204 & -0.03 & {$[-0.05 ;-0.01]$} & $* *$ \\
\hline Mineral soil & 1 & $\leq 3.2$ & 29 & 0.25 & {$[0.15 ; 0.4]$} & $* *$ \\
$(10-20 \mathrm{~cm})$ & 2 & $3.2-4$ & 564 & 0.09 & {$[0.07 ; 0.12]$} & $* *$ \\
& 3 & $4-5$ & 934 & -0.03 & {$[-0.06 ;-0.01]$} & $* *$ \\
& 4 & $5-6$ & 149 & -0.22 & {$[-0.32 ;-0.11]$} & $* *$ \\
& 5 & $>6$ & 434 & -0.18 & {$[-0.23 ;-0.14]$} & $* *$ \\
& - & whole & 2110 & -0.04 & {$[-0.06 ;-0.02]$} & $* *$ \\
\hline Mineral soil & 1 & $\leq 3.2$ & 7 & 0.65 & {$[0.46 ; 0.87]$} & $* *$ \\
$(20-40 \mathrm{~cm})$ & 2 & $3.2-4$ & 171 & 0.20 & {$[0.13 ; 0.3]$} & $* *$ \\
& 3 & $4-5$ & 311 & -0.08 & {$[-0.11 ;-0.03]$} & $* *$ \\
& 4 & $5-6$ & 33 & -0.03 & {$[-0.27 ; 0.29]$} & ns \\
& 5 & $>6$ & 146 & -0.34 & {$[-0.47 ;-0.25]$} & $* *$ \\
& - & whole & 668 & -0.06 & {$[-0.1 ;-0.01]$} & $* *$ \\
\hline Mineral soil & 2 & $\leq 4$ & 74 & 0.14 & {$[0.07 ; 0.32]$} & $* *$ \\
$(40-80 \mathrm{~cm})$ & 3 & $4-5$ & 240 & -0.04 & {$[-0.08 ; 0.03]$} & ns \\
& 4 & $5-6$ & 32 & -0.11 & {$[-0.34 ; 0.2]$} & ns \\
& 5 & $>6$ & 87 & -0.27 & {$[-0.42 ;-0.14]$} & $* *$ \\
& - & whole & 433 & -0.06 & {$[-0.1 ;-0.003]$} & $* *$ \\
\hline
\end{tabular}


- The distinction between "total" (or extractable by aqua regia) and "total total" (complete destruction of the sample) analysis have been made following ISO standards.

All laboratories reporting soil data to the database had to use the reference methods:

- The reference methods follow the ISO standards whenever applicable.

- The laboratory performance is followed up by interlaboratory comparisons every other year.

- During the BioSoil survey, the laboratories could use the FSCC soil reference material for internal quality control.

Forest floor and soil classification:

- Harmonised definitions of humus forms and the application of the general level of the European Humus Classification System (advised by Zanella et al. 2009).

- Supporting profile description and laboratory analyses are mandatory according to FAO (2006) based guidelines.

- The classification following the World Reference Base for Soil Resources 2006 (IUSS Working Group WRB 2007) is mandatory.

Geographically there is a substantial improvement in the overlay with the tree vitality inventory on the Level I plots. In the first inventory the forest soil condition was often conducted on (a subset of) national forest inventory plots while in the BioSoil survey, the systematic $16 \times 16 \mathrm{~km}$ grid has been better respected and provides a representative sample of the forest soils in Europe.

\section{Change in $\mathrm{pH}\left(\mathrm{CaCl}_{2}\right)$ and base saturation on the Level I plots}

The first and the second pan-European forest soil surveys have more than 2000 Level I plots in common where the $\mathrm{pH}\left(\mathrm{CaCl}_{2}\right)$ in the upper $10 \mathrm{~cm}$ of the mineral soil is available. Although there has been a minor change in the reference method, where previously the 1:5 ratio was measured on weight basis where currently a volumetric basis is used, it may be assumed that methodological differences are minor for this soil variable. This assumption is further supported by the small coefficients of variation for $\mathrm{pH}\left(\mathrm{CaCl}_{2}\right)$ in the $\mathrm{FSCC}$ interlaboratory comparisons which have been conducted at regular time intervals between both surveys.

To gain a better understanding in the changes of the $\mathrm{pH}\left(\mathrm{CaCl}_{2}\right)$, the variable has been split into five classes. The same $\mathrm{pH}\left(\mathrm{CaCl}_{2}\right)$ class limits as applied in the Forest Soil Condition Report (Vanmechelen et al. 1997) have been used ( $\mathrm{pH} \leq 3.2,3.2<$ $\mathrm{pH} \leq 4.0,4.0<\mathrm{pH} \leq 5.0,5.0<\mathrm{pH} \leq 6.0$ and $\mathrm{pH}>6.0)$ to allow comparability with the first inventory.

A second important forest soil property is the base saturation (BS). The changes in \% BS between the first and the second inven-

Tab. 6 - The plotwise paired mean difference in \% base saturation (BS) in the forest floor and the four fixed depth mineral layers $(0-10 \mathrm{~cm}, 10-20 \mathrm{~cm}, 20-40 \mathrm{~cm}$ and $40-80 \mathrm{~cm}) \mathrm{ac}$ cording to 5 classes for common plots in the Level I surveys of 1985-1996 and 2004-2008. The last 2 columns show the $95 \%$ confidence interval after bootstrapping the mean difference and an indication if this mean difference is significant different from zero (no change). $\left({ }^{* *}\right)$ : significant at $95 \%$ confidence limits; $(*)$ : significant at $90 \%$ confidence limits; (a): when statistically significant at the $90 \%$ but not at the $95 \%$ significance level; the $90 \%$ confidence interval is given; (ns): non significant.

\begin{tabular}{|c|c|c|c|c|c|c|}
\hline Layer & $\begin{array}{l}\text { BS } \\
\text { class }\end{array}$ & $\begin{array}{c}\text { BS range } \\
(\%)\end{array}$ & $\begin{array}{c}\text { No. } \\
\text { observations }\end{array}$ & $\begin{array}{c}\text { Mean } \\
\text { difference }\end{array}$ & $\begin{array}{l}95 \% \\
\text { C.I. }{ }^{a}\end{array}$ & Prob. \\
\hline Forest Floor & 1 & $\leq 50$ & 67 & 5.0 & {$[2.5 ; 7.5]$} & $* *$ \\
\hline \multirow[t]{5}{*}{ (OF \& OH layer) } & 2 & $50-60$ & 97 & -1.6 & {$[-3.5 ; 0.3]$} & ns \\
\hline & 3 & $60-70$ & 101 & -4.7 & {$[-6.3 ;-2.9]$} & $* *$ \\
\hline & 4 & $70-80$ & 82 & -7.6 & {$[-9.5 ;-5.9]$} & $* *$ \\
\hline & 5 & $>80$ & 62 & -8.7 & {$[-10.8 ;-6.7]$} & $* *$ \\
\hline & - & whole & 409 & -3.5 & {$[-4.6 ;-2.5]$} & $* *$ \\
\hline Mineral topsoil & 1 & $\leq 10$ & 165 & 5.8 & {$[4.3 ; 8.3]$} & $* *$ \\
\hline \multirow[t]{5}{*}{$(0-10 \mathrm{~cm})$} & 2 & $10-20$ & 301 & 5.2 & {$[3.7 ; 7]$} & $* *$ \\
\hline & 3 & $20-50$ & 413 & -1.8 & {$[-3.2 ;-0.2]$} & $*$ \\
\hline & 4 & $50-95$ & 344 & -5.5 & {$[-7.5 ;-3.6]$} & $* *$ \\
\hline & 5 & $>95$ & 336 & -2.9 & {$[-4.1 ;-2.1]$} & $* *$ \\
\hline & - & whole & 1559 & -0.7 & {$[-1.4 ; 0.1]$} & ns \\
\hline Mineral soil & 1 & $\leq 10$ & 226 & 5.7 & {$[4.2 ; 8]$} & $* *$ \\
\hline \multirow[t]{5}{*}{$(10-20 \mathrm{~cm})$} & 2 & $10-20$ & 262 & 4.7 & {$[3.1 ; 6.6]$} & $* *$ \\
\hline & 3 & $20-50$ & 428 & -1.7 & {$[-3.5 ; 0.1]$} & ns \\
\hline & 4 & $50-95$ & 303 & -8.7 & {$[-11 ;-6.2]$} & $* *$ \\
\hline & 5 & $>95$ & 280 & -3.7 & {$[-5.5 ;-2.5]$} & $* *$ \\
\hline & - & whole & 1499 & -1.3 & {$[-2.2 ;-0.3]$} & $* *$ \\
\hline Mineral soil & 1 & $\leq 10$ & 126 & 5.7 & {$[3.5 ; 9.7]$} & $* *$ \\
\hline \multirow[t]{5}{*}{$(20-40 \mathrm{~cm})$} & 2 & $10-20$ & 100 & 3.6 & {$[0.5 ; 7.7]$} & $* *$ \\
\hline & 3 & $20-50$ & 133 & -8.0 & {$[-10.9 ;-4.7]$} & $* *$ \\
\hline & 4 & $50-95$ & 122 & -14.5 & {$[-19 ;-9.9]$} & $* *$ \\
\hline & 5 & $>95$ & 177 & -3.3 & {$[-6.1 ;-1.9]$} & $* *$ \\
\hline & - & whole & 658 & -3.6 & {$[-5.1 ;-2]$} & $* *$ \\
\hline Mineral soil & 1 & $\leq 10$ & 21 & 4.0 & {$[1 ; 11.3]$} & $* *$ \\
\hline \multirow[t]{5}{*}{$(40-80 \mathrm{~cm})$} & 2 & $10-20$ & 27 & 4.6 & {$[-1.4 ; 16.9]$} & ns \\
\hline & 3 & $20-50$ & 31 & -7.9 & {$[-13.6 ;-1.1]$} & $* *$ \\
\hline & 4 & $50-95$ & 36 & -7.2 & {$[-15.3 ;-0.7]$} & $*$ \\
\hline & 5 & $>95$ & 43 & -0.8 & {$[-2.9 ;-0.1]$} & $* *$ \\
\hline & - & whole & 158 & -0.8 & {$[-5.2 ; 0.8]$} & ns \\
\hline
\end{tabular}

tory are compared. The BS has been calculated as the sum of the basic exchangeable cations $(\mathrm{Ca}, \mathrm{Mg}, \mathrm{K}$ and $\mathrm{Na})$ to the effective cation exchange capacity of the soil (by extraction in a unbuffered $\mathrm{BaCl}_{2}$ solution). Similar to the $\mathrm{pH}\left(\mathrm{CaCl}_{2}\right)$ the $\mathrm{BS}$ values were split into five classes following the limits used in the evaluation of the first inventory: $\mathrm{BS} \leq 10 \%, 10 \%<\mathrm{BS} \leq 20 \%, 20<\mathrm{BS} \leq$ $50 \%, 50<\mathrm{BS} \leq 95 \%$ and $\mathrm{BS}>95 \%$. As the BS in the forest floor was never below $20 \%$ or above $95 \%$, different classes limits were applied for this forest floor: $\mathrm{BS} \leq 50 \%, 50<$ $\mathrm{BS} \leq 60 \%, 60<\mathrm{BS} \leq 70 \%, 70<\mathrm{BS} \leq 80 \%$ and $\mathrm{BS}>80 \%$

A second stratification was conducted following the Reference Soil Groups of the WRB Soil Classification (IUSS Working Group WRB 2006, 2007) both for the $\mathrm{pH}\left(\mathrm{CaCl}_{2}\right)$ and the BS values in the forest floor and the mineral soil layer $0-10,10-20$, and $20-40 \mathrm{~cm}$.

Statistics were calculated using the TIBCO
SPOTfiRe S+ 8.1 FOR Windows (2008). Bootstrapping was used as a resampling technique to obtain confidence intervals (C.I.s) for the plotwise paired mean difference in soil $\mathrm{pH}\left(\mathrm{CaCl}_{2}\right)$ between the two surveys. In the bootstrap, B new samples, each of the same size as the observed data, are drawn with replacement from the observed data. For more information on the bootstrapping technique, see Johnson et al. (1990). The applied number of resamples (B) was 5000 . Confidence intervals were calculated based on bias-corrected and accelerated (Bca) percentiles at 2.5 and $97.5 \%$, respectively.

\section{Results and discussion}

Mean paired differences of $\mathrm{pH}\left(\mathrm{CaCl}_{2}\right)$ and BS were computed for each Level I plot as the difference between the values of the second value minus the value of the first survey where negative values indicate a decrease of the variable relative to the first survey. Tab. 5 shows an overall significant de- 
Tab. 7 - The plotwise paired mean difference in $\mathrm{pH}\left(\mathrm{CaCl}_{2}\right)$ and \% base saturation (BS) in the forest floor and three fixed mineral layers $(0$ $10 \mathrm{~cm}, 10-20 \mathrm{~cm}$ and 20-40 cm) according to the most frequently found WRB Reference Soil Groups (RSG) on common plots in the Level I surveys of 1985-1996 and 2004-2008. (**): significant at 95\% significance level; (*): significant at 90\% significance level; (a): The 90\% confidence interval is given when it was significant at the $90 \%$ thought not significant at the $95 \%$ significance level; (ns): non significant.

\begin{tabular}{|c|c|c|c|c|c|c|c|c|c|}
\hline \multirow[b]{2}{*}{ Layer } & \multirow{2}{*}{$\begin{array}{c}\text { WRB } \\
\text { RSG }\end{array}$} & \multicolumn{3}{|c|}{ pH $\left(\mathrm{CaCl}_{2}\right)$} & \multirow[b]{2}{*}{ Prob. } & \multicolumn{3}{|c|}{ \% base saturation } & \multirow[b]{2}{*}{ Prob. } \\
\hline & & $\begin{array}{l}\text { No. } \\
\text { plots }\end{array}$ & $\begin{array}{c}\text { Mean } \\
\text { difference }\end{array}$ & 95\% C.I. ${ }^{a}$ & & $\begin{array}{l}\text { No. } \\
\text { plots }\end{array}$ & $\begin{array}{c}\text { Mean } \\
\text { difference }\end{array}$ & 95\% C.I. ${ }^{a}$ & \\
\hline \multirow[t]{9}{*}{ Forest floor } & Cambisols & 335 & 0.09 & {$[0.05 ; 0.14]$} & $* *$ & 57 & -1.7 & {$[-4.9 ; 1.1]$} & - \\
\hline & Regosols & 302 & 0.02 & {$[-0.04 ; 0.06]$} & - & 153 & -3.9 & {$[-5.5 ;-2.3]$} & $* *$ \\
\hline & Podzols & 196 & -0.05 & {$[-0.10 ;-0.001]$} & $* *$ & 121 & -4.0 & {$[-5.6 ;-2.4]$} & $* *$ \\
\hline & Arenosols & 135 & -0.09 & {$[-0.16 ;-0.01]$} & $* *$ & 44 & -6.2 & {$[-9.4 ;-3.7]$} & $* *$ \\
\hline & Luvisols & 92 & 0.10 & {$[0.01 ; 0.19]$} & $*$ & 2 & - & - & - \\
\hline & Leptosols & 135 & -0.06 & {$[-0.17 ; 0.03]$} & - & 14 & -6.9 & {$[-9.6 ;-4.2]$} & $* *$ \\
\hline & Umbrisols & 55 & 0.02 & {$[-0.08 ; 0.17]$} & - & 1 & - & - & - \\
\hline & Stagnosols & 30 & 0.05 & {$[-0.05 ; 0.15]$} & - & 16 & 4.7 & {$[-3.2 ; 11.4]$} & - \\
\hline & Gleysols & 21 & 0.01 & {$[-0.26 ; 0.32]$} & - & 0 & - & - & - \\
\hline \multirow[t]{9}{*}{$0-10 \mathrm{~cm}$} & Cambisols & 645 & -0.02 & {$[-0.06 ; 0.02]$} & - & 498 & 0.7 & {$[-0.8 ; 2.2]$} & - \\
\hline & Regosols & 368 & -0.04 & {$[-0.08 ;-0.008]$} & $* *$ & 275 & -0.3 & {$[-4.7 ;-0.9]$} & $* *$ \\
\hline & Podzols & 252 & -0.01 & {$[-0.06 ; 0.03]$} & - & 181 & -0.8 & {$[-2.4 ; 0.9]$} & - \\
\hline & Arenosols & 182 & -0.08 & {$[-0.13 ;-0.02]$} & $* *$ & 145 & -3.7 & {$[-6.4 ;-0.8]$} & $* *$ \\
\hline & Luvisols & 146 & 0.01 & {$[-0.08 ; 0.09]$} & - & 104 & 3.9 & {$[0.8 ; 7.8]$} & $* *$ \\
\hline & Leptosols & 213 & -0.06 & {$[-0.11 ;-0.002]$} & $*$ & 89 & 1.0 & {$[-0.4 ; 3.6]$} & - \\
\hline & Umbrisols & 82 & -0.03 & {$[-0.15 ; 0.07]$} & - & 60 & -4.4 & {$[-8.8 ; 1.4]$} & - \\
\hline & Stagnosols & 57 & -0.01 & {$[-0.10 ; 0.08]$} & - & 53 & -4.2 & {$[-8.7 ;-0.1]$} & $*$ \\
\hline & Gleysols & 48 & 0.04 & {$[-0.12 ; 0.19]$} & - & 33 & 5.6 & {$[1.3 ; 11.5]$} & $* *$ \\
\hline \multirow{9}{*}{$10-20 \mathrm{~cm}$} & Cambisols & 610 & -0.06 & {$[-0.1 ;-0.02]$} & $* *$ & 472 & -1.2 & {$[-2.8 ; 0.4]$} & - \\
\hline & Regosols & 361 & -0.03 & {$[-0.06 ;-0.002]$} & $*$ & 272 & -1.2 & {$[-3.6 ; 1]$} & - \\
\hline & Podzols & 232 & 0.00 & {$[-0.04 ; 0.03]$} & - & 181 & -1.3 & {$[-3.2 ; 0.7]$} & - \\
\hline & Arenosols & 166 & -0.05 & {$[-0.09 ;-0.006]$} & $*$ & 144 & -1.4 & {$[-4.7 ; 1.7]$} & - \\
\hline & Luvisols & 140 & -0.01 & {$[-0.10 ; 0.08]$} & - & 105 & 3.6 & {$[0.1 ; 7.7]$} & $*$ \\
\hline & Leptosols & 177 & -0.02 & {$[-0.08 ; 0.05]$} & - & 70 & 1.5 & {$[-0.6 ; 4.3]$} & - \\
\hline & Umbrisols & 78 & -0.04 & {$[-0.10 ; 0.05]$} & - & 58 & -10.6 & {$[-16.4 ;-4.1]$} & $* *$ \\
\hline & Stagnosols & 53 & 0.01 & {$[-0.07 ; 0.15]$} & - & 52 & -4.0 & {$[-7.6 ;-0.4]$} & $*$ \\
\hline & Gleysols & 46 & -0.02 & {$[-0.2 ; 0.16]$} & - & 32 & 0.2 & {$[-5.2 ; 7.0]$} & - \\
\hline \multirow{9}{*}{$20-40 \mathrm{~cm}$} & Cambisols & 290 & -0.04 & {$[-0.10 ; 0.03]$} & - & 288 & -0.7 & {$[-2.7 ; 1.4]$} & - \\
\hline & Regosols & 64 & -0.10 & {$[-0.24 ;-0.009]$} & $* *$ & 61 & -8.7 & {$[-15.3 ;-3.5]$} & $* *$ \\
\hline & Podzols & 37 & 0.10 & {$[-0.006 ; 0.22]$} & - & 36 & -1.1 & {$[-7.4 ; 5.8]$} & - \\
\hline & Arenosols & 64 & 0.01 & {$[-0.04 ; 0.07]$} & - & 64 & -8.7 & {$[-12.5 ;-5.2]$} & $* *$ \\
\hline & Luvisols & 24 & 0.00 & {$[-0.30 ; 0.36]$} & - & 24 & 0.1 & {$[-12.1 ; 13.5]$} & - \\
\hline & Leptosols & 24 & -0.06 & {$[-0.31 ; 0.10]$} & - & 2 & - & - & - \\
\hline & Umbrisols & 34 & -0.11 & {$[-0.22 ; 0.03]$} & - & 34 & -6.9 & {$[-14.7 ; 2.3]$} & - \\
\hline & Stagnosols & 34 & -0.06 & {$[-0.29 ; 0.08]$} & - & 34 & -11.2 & {$[-18.8 ;-6.1]$} & $* *$ \\
\hline & Gleysols & 21 & -0.23 & {$[-0.50 ;-0.005]$} & $* *$ & 20 & -1.9 & {$[-12.3 ; 6.9]$} & - \\
\hline
\end{tabular}

crease of $0.03 \mathrm{pH}$ units in the $0-10 \mathrm{~cm}$ mineral soil layer on 2204 plots. With increasing soil depth, the data availability decreases, though an increasing difference till $0.06 \mathrm{pH}$ units is seen in the deeper soil layers.

The stratification according to five $\mathrm{pH}$ classes allows more differentiation within this general picture. A statistical significant increase in $\mathrm{pH}\left(\mathrm{CaCl}_{2}\right)$ between the second and the first soil inventory of $0.27 \mathrm{pH}$ units is seen in the upper mineral soil layer in soils with a reference $\mathrm{pH}$ (first survey) lower than or equal to 3.2. In the $\mathrm{pH}$ class 3.2 to 4.0 , this significant increase comes down to 0.05 $\mathrm{pH}$ units. In the higher $\mathrm{pH}$ classes, an opposite trend is seen, namely a decrease between 0.04 and $0.19 \mathrm{pH}$ units. Similar trends could be found in the deeper mineral soil layers. Note that the available data for the $40-80 \mathrm{~cm}$ in the first inventory was limited to only 4 countries (433 plots) of which two countries only sampled up to $60 \mathrm{~cm}$ depth. In the organic layers statistically significant differences were seen in $\mathrm{pH}$ class 1 (increase) and $\mathrm{pH}$ class 5 (decrease).

Tab. 6 shows that the BS in the mineral soil significantly increases with 4 to $6 \%$ in all mineral soil layers up to $40 \mathrm{~cm}$ depth when the reference BS (first survey) was below $20 \%$. When the BS in the first survey was above $20 \%$, a statistically significant decrease is observed between 1 and $15 \%$ in most of the mineral soil layers. In the forest floor, where the level of BS is higher compared to the mineral soil, a statistically positive trend (increase in BS of 5\%) is seen when BS was below $50 \%$ and a statistically negative trend (decrease between 5 and 9\%) when the BS was above $60 \%$.

Tab. 7 shows the results of the stratifica- tion of the changes in $\mathrm{pH}\left(\mathrm{CaCl}_{2}\right)$ and \% BS according to the nine most frequently described WRB Reference Soil Groups (RSG) on the Level I plots. The information on the $40-80 \mathrm{~cm}$ layer is not shown as the data availability is rather limited. The trend when stratifying according the RSGs is less straightforward compared to the trends seen in the stratification according to the $\mathrm{pH}$ and BS classes. There is a decrease of soil $\mathrm{pH}$ and BS in the forest floor of the Arenosols and Podzols. In the Podzols this decreasing trend did not persist in the mineral soil though this decreasing trend continued in a number of mineral soil layers of the Arenosols. The only consistent increasing trend of $\mathrm{pH}$ and $\mathrm{BS}$ was seen in the forest floor of the Luvisols and Cambisols.

As $\mathrm{pH}\left(\mathrm{CaCl}_{2}\right)$ and $\mathrm{BS}$ are strongly correlated in forest soils (Blaser et al. 2008, Van- 
mechelen et al. 1997), the analyses of the trend for both properties seem to show a recovery after acidification in the most acid forest soils [with $\mathrm{pH}\left(\mathrm{CaCl}_{2}\right) \leq 4.0$ or $\mathrm{BS} \leq$ $20 \%$ ]. These acid and/or strongly leached soils are mainly found in north and northwest Europe. These findings are supported by the study of Matschonat \& Falkengren-Grerup (2000) who observed in southern Sweden between 1988 and 1996 increase in the exchange saturation and $\mathrm{pH}$ only in those soils with small cation exchange capacity and low buffering capacity. Also Vanguelova et al. (2010) found a recovery of soil pH between 1995 and 2006 on sites with very low buffering capacities. On the other hand a further acidification between roughly 1994 and 2006 is observed on the forest soils with $\mathrm{pH}\left(\mathrm{CaCl}_{2}\right)$ above 4.0 or a base saturation above $20 \%$ in the mineral soil. One possible explanation for the observed changes is the decreased atmospheric deposition. Soils with relatively high $\mathrm{pH}$, base saturation and cation exchange capacity are better represented in the southern parts of Europe. While atmospheric deposition has decreased whole over Europe over the past three decades (Driscoll et al. 2006), also the deposition of base cations decreased (Hedin et al. 1994, Likens et al. 1996). This decrease might have a different influence on base saturation in a variety of soil types in different part of Europe. Draaijers et al (1997) showed that soils in eastern and southern Europe mainly rely on atmospheric deposition for the supply of base cations while in Scandinavia weathering is the dominant supplier of basic cations.

These trends of recovery and decrease of soil $\mathrm{pH}$ and $\mathrm{BS}$ are similar in the $0-10 \mathrm{~cm}$ and $10-20 \mathrm{~cm}$ layers while the difference in the lowest and highest $\mathrm{pH}$ classes and highest BS classes are more explicit in the 20-40 cm layer. Based on the current knowledge of forest soil acidification and the related recovery processes, these trends are hard to explain. Sverdrup et al. (2005) postulated rather a poorer recovery with increasing soil depth based on the theory that due to differences in properties of individual soil horizons, different parts of the soil profile acidify and recover at different rates. In the acidification process, there could be a significant delay from the topsoil, which is first affected by acid deposition, to the bottom of the soil profile. During acidification, hydrogen and $\mathrm{Al}^{+}$ions mobilized in the soil solution may exchange with the base cations on a cation exchangeable complex and delay the decrease in $\mathrm{pH}$. During recovery, the reverse process could occur, and while the upper layers recover, simultaneously the bottom layers may still acidify. This phenomenon will be further investigated based on the gradients in $\mathrm{pH}$ and $\mathrm{BS}$ within each forest soil profile.
Further investigations on possible relationships between the established changes in $\mathrm{pH}$ and base saturation with other soil variables such as exchange capacity of the soil, soil texture, organic carbon content, nitrogen and anthropogenic pollutants (such as $\mathrm{Pb}$ ) will be conducted. These correlation studies will lead to a better understanding of the detected changes.

The classification of the Level I plots according to the World Reference Base for Soil Resources (IUSS Working Group WRB $2006,2007)$ provides an important added value of the ICP Forests database as this harmonised information cannot be deduced from soil maps at the European scale (such as the Soil Atlas of Europe by the European Soil Bureau Network - European Commission 2005) as these maps are mainly based on data from agricultural land whereas the situation in forests might be completely different.

\section{Conclusions}

The ICP Forests soil database provides a very valuable basis for the monitoring of forest soil data. An often overlooked but very important benefit of the ICP Forests databases in comparison with other PanEuropean forest databases, is that the data have been collected by applying harmonised methods both in the field and in the laboratory and that the laboratory performance is guarded by regular interlaboratory comparisons. The current Level I database contains 2421 plots included in two forest soil inventories with an average time interval of 12 years enabling statistical powerful comparisons. Notwithstanding the limitiation that a number of parameters and laboratory methods have changed over time, the variables $\mathrm{pH}\left(\mathrm{CaCl}_{2}\right)$, organic carbon, total nitrogen, exchangeable elements and aqua regia extractable elements in the mineral and organic layer offer valuable monitoring information on the status and trends of European forest soil condition. Over a period of approximately 12 years (1994-2006) statistically significant changes in soil $\mathrm{pH}$ and base saturation could be established. It however asks for more in depth investigations to fully understand these changes.

\section{Acknowledgements}

The authors wish to acknowledge the ICP Forests National Focal Centres of Austria, Belgium, Czech Republic, Cyprus, Denmark, Estonia, Finland, France, Germany, Greece, Hungary, Ireland, Italy, Latvia, Lithuania, Poland, Portugal, Serbia, Slovenia, Slovak Republic, Spain and the United Kingdom for making the BioSoil data available to the Forest Soil Coordinating Centre for analysis and evaluation at the European level within the framework of the FutMon project under the LIFE+ Regulation (EC)
No. 614/2007 of the European Parliament and of the Council. Financial support for the data collection of both survey was granted by the European Commission through Commission Regulation (EEC) No. 926/93 (CEC 1993 ) and the European Commission Forest Focus Regulation (EC) No. 2152/2003 (EC 2003).

\section{References}

Blaser P, Graf Pannatier E, Walthert L (2008). The base saturation in acidified Swiss forest soils on calcareous and noncalcareous parent material. A pH-base saturation anomaly. Journal of Plant Nutrition and Soil Science 171 (2): 155-162. doi: 10.1002/(ISSN)1522-2624

CEC (1993). Commission Regulation (EEC) No 926/93 of 1 April 1993. OJL 100, 26.4.1993, pp. $1-47$

EC (2003). Regulation (EC) No 2152/2003 of the European Parliament and of the of 17 November 2003 concerning monitoring of forests and environmental interactions in the Community (Forest Focus). OJL 324, 11.12.2003, pp. 1-8.

Cools N, Delanote V, De Vos B, Quataert P, Roskams P, Scheldeman X (2003). Quality assurance and quality control in forest soil analysis: $3^{\text {rd }}$ FSCC interlaboratory comparison. Forest soil co-ordinating centre, Rapporten van het Instituut voor Bosbouw en Wildbeheer - sectie bosbouw 2003 (018). Institute for Forestry and Game Management, Geraardsbergen, Belgium, pp. 83.

Cools N, Delanote V, Scheldeman X, Quataert P, De Vos B, Roskams P (2004). Quality assurance and quality control in forest soil analyses: a comparison between European soil laboratories. Accreditation and Quality Assurance 9: 688-694. doi: 10.1007/s00769-004-0856-4

Cools N, Verschelde P, Quataert P, Mikkelsen JH, De Vos B (2006). Quality assurance and quality control in forest soil analysis: $4^{\text {th }}$ FSCC interlaboratory comparison. INBO.R.2006.6. Forest Soil Coordinating Centre, Research Institute for Nature and Forest, Geraardsbergen, Belgium, pp. 66.

Cools N, Mikkelsen JH, De Vos B (2007). Quality assurance and quality control in forest soil analysis: $5^{\text {th }}$ FSCC interlaboratory comparison. INBO.R.2007.46. Forest soil coordinating centre, Research Institute for Nature and Forest, Geraardsbergen, Belgium, pp. 63.

Cools N, De Vos B (2010a). Sampling and analysis of soil. Manual Part X, In: "Manual on methods and criteria for harmonized sampling, assessment, monitoring and analysis of the effects of air pollution on forests". UNECE, ICP Forests, Hamburg. ISBN: 978-3-926301-03-1. pp. 208. [online] URL: http://www.icp-forests.org/Manual.htm

Cools N, De Vos B (2010b). $6^{\text {th }}$ FSCC interlaboratory comparison 2009. Rapporten van het Instituut voor Natuur- en Bosonderzoek 2010. INBO.R.2010.4. Research Institute for Nature and Forests, Brussels, Belgium, pp. 52.

De Schrijver A, Nachtergale L, Roskams, P, De 
Keersmaeker L, Mussche S, Lust, N (1998). Soil acidification along an ammonium deposition gradient in a Corsican Pine stand in northern Belgium. Environmental Pollution 102: $427-$ 431. - doi: 10.1016/S0269-7491(98)80064-X Draaijers G, Van Leeuwen E, De Jong P, Erisman J (1997). Base-cation deposition in Europe part II. Acid neutralization capacity and contribution to forest nutrition. Atmospheric Environment 31 (24): 4159-4168. - doi: 10.1016/S1352-2310(97) 00253-7

Driscoll CT, Fallon-Lambert K, Chen L (2006). Acidic deposition: sources and effects. Encyclopedia of Hydrological Sciences, John Wiley \& Sons, NY, USA.

Eriksson E, Karltum E, Lundmark JE (1992). Acidification of forest soils in Sweden. Ambio 21: $150-154$.

European Commission (2005). Soil atlas of Europe. European Soil Bureau Network, Office for Official Publications of the European Communities, EUR 21676 EN, Luxembourg, pp. 128. FAO (1990). Guidelines for soil profile description ( $3^{\text {rd }}$ edn.). FAO, Rome, Italy, pp. 70.

FAO (2006). Guidelines for soil description ( $4^{\text {th }}$ edn.). FAO, Rome, Italy, pp. 97.

Fischer R, Mues V, Ulrich E, Becher G, Lorenz M (2007). Monitoring of atmospheric deposition in European forests and an overview on its implication on forest condition. Applied Geochemistry 22 (6): 1129-1139. - doi: 10.1016/j.apgeochem. 2007.03.004

Hedin LO, Granat L, Likens GE, Buishand TA, Galloway JN, Butler TJ, Rodhe H (1994). Steep declines in atmospheric base cations in regions of Europe and North America. Nature 367: 351 . 354 - doi: 10.1038/367351a0

Fernandez IJ, Rustad LE, Norton SA, Kahl JS, Cosby BJ (2003). Experimental acidification causes soil base-cation depletion at the Bear Brook Watershed in Maine. Soil Science Society of America Journal 67 (3): 1909-1919. - doi: 10.2136/sssaj2003.1909

Hernandez L (2003). Heavy metal distribution in some French forest soils: evidence for atmo- spheric contamination. The Science of The Total Environment 312 (1-3): 195-219. - doi: 10.1016/ S0048-9697(03)00223-7

IUSS Working Group WRB (2006). World reference base for soil resources 2006. FAO, Rome, Italy, pp. 128.

IUSS Working Group WRB (2007). World reference base for soil resources 2006 (first update 2007). FAO, Rome, Italy, pp. 116.

ISO 11277 (1998). Soil quality - determination of particle size distribution in mineral soil material - method by sieving and sedimentation. International Organization for Standardization, Geneva, Switzerland, pp. 30

Johnson CE, Johnson AH, Huntington TG (1990). Sample size requirements for the determination of changes in soil nutrient pools. Soil Science 150 (3): 637-644. - doi: 10.1097/00010694199009000-00010

Lambert JJ, Daroussin J, Eimberck M, Le Bas C, Jamagne M, King D, Montanarella L (2003). Soil geographical database for Eurasia \& the Mediterranean: instructions guide for elaboration at scale 1:1.000.000. Version 4.0. EUR 20422 EN. Office for Official Publications of the European Communities, Luxembourg, pp. 64.

Likens GE, Driscoll CT, Buso DC (1996). Longterm effects of acid rain: response and recovery of a forest ecosystem. Science 272: 244-246. doi: $10.1126 /$ science. 272.5259 .244

Lorenz M, Granke O (2009). Deposition measurements and critical loads calculations: monitoring data, results and perspective. iForest 2: 11-14. doi: 10.3832/ifor0478-002

Matschonat G, Falkengren-Grerup U (2000). Recovery of soil $\mathrm{pH}$, cation-exchange capacity and the saturation of exchange sites from stemflow-induced soil acidification in three Swedish beech (Fagus sylvatica L.) forests. Scandinavian Journal of Forest Research 15 (1): 39-48. - doi: 10.1080/02827580050160457

Nilsson SI, Tyler G (1995). Acidification-induced chemical changes of forest soils during recent decades: a review. Ecological Bulletins 44: 5464. [online] URL: http://www.jstor.org/stable/
20113149

Sverdrup H, Martinson L, Alveteg M, Moldan F, Kronnäs V, Munthe J (2005). Modeling recovery of Swedish ecosystems from acidification.. Ambio 34 (1): 25-31. [online] URL: http://www. ncbi.nlm.nih.gov/pubmed/15789515

UN-ECE (1994). United nations economic commission for Europe: convention on long-range transboundary air pollution. International cooperative programme on assessment and monitoring of air pollution effects on forests. Manual on methodologies and criteria for harmonized sampling, assessment, monitoring and analysis of the effects of air pollution on forests.

van Breemen N, Burrough PA, Velthorst EJ, van Dobben HF, de Wit T, Ridder TB, Reijnders HF (1982). Soil acidification from atmospheric ammonium sulphate in forest canopy throughfall. Nature 299 (5883): 548-550. - doi: 10.1038/ $299548 \mathrm{a} 0$

van Breemen N, Driscoll CT, Mulder J (1984). Acid deposition and internal proton sources in acidification of soils and waters. Nature 307: 599-604. - doi: 10.1038/307599a0

Vanmechelen L, Groenemans R, van Ranst E (1997). Forest soil condition in Europe. Results of a large-scale soil survey. Forest soil co-ordinating centre, Brussels, Belgium, pp. 261.

Vanguelova EI, Benham S, Pitman R, Moffat AJ, Broadmeadow M, Nisbet T, Durrant D, Barsoum $\mathrm{N}$, Wilkinson $\mathrm{M}$, Bochereau $\mathrm{F}$, Hutchings $\mathrm{T}$, Broadmeadow S, Crow P, Taylor P, Durrant Houston T (2010). Chemical fluxes in time through forest ecosystems in Sweden and the UK - soil response to pollution recovery. Environmental Pollution 158 (5): 1857-1869. - doi: 10.1016/j.envpol.2009.10.044

Zanella A, Jabiol B, Ponge JF, Sartori G, De Waal R, Van Delft B, Graefe U, Cools N, Katzensteiner K, Hager H, Englisch M, Brêthes A (2009). Towards a European humus forms reference base. Studi Trentini di Scienze Naturali 85: 145 151. [online] URL: http://hal.archives-ouvertes. fr/docs/00/49/46/15/PDF/Zanella_et_al._2009.p $\mathrm{df}$ 